\title{
An Insight into Total Soluble Proteins across Rice (Oryza sativa L.) Germplasm Accessions
}

\author{
S. Aiyswaraya ${ }^{1 *}$, R. Saraswathi ${ }^{1}$, S. Ramchander ${ }^{1}$, R. Vinoth $^{1}$, \\ D. Uma ${ }^{2}$, D. Sudhakar ${ }^{3}$ and S. Robin ${ }^{1}$ \\ ${ }^{1}$ Department of Rice, Centre for Plant Breeding and Genetics, Tamil Nadu Agricultural \\ University, Coimbatore-641003, Tamil Nadu, India \\ ${ }^{2}$ Department of Plant Biochemistry, ${ }^{3}$ Department of Biotechnology, Centre for Plant Molecular \\ Biology and Biotechnology, Tamil Nadu Agricultural University, \\ Coimbatore-641003, Tamil Nadu, India \\ *Corresponding author
}

\begin{tabular}{|l|}
\hline K e y w o r d s \\
Rice, Total soluble \\
proteins, Landraces, \\
Germplasm, \\
Clustering.
\end{tabular}

\section{Introduction}

Among cereals, rice is one of the staple foods for more than half of the world's population and it has defined the culture, diets and economies of billions of people. In Asia, it has a very long history of cultivation and is deeply rooted in the daily lives of people (Narayanan et al., 2000). Cereals based food habits had created the situation of under nutrition and it is one of the ever increasing issues in the developing world most 
vulnerable to the protein deficiency. Only twenty per cent of the people in the world have access to nutritious diet. Protein energy malnutrition approximately affects 230 million of children in developing countries (WHO Bulletin, 1993).

In India, more than 50 per cent of children received insufficient calories everyday to meet their potential growth and development requirements (Mahendra et al., 2004). SubSaharan Africa and South Asia are expected to remain "Hot Spots" of child malnutrition in 2020 (Andersen et al., 1999).

Studies on children recovering from protein energy malnutrition demonstrated that essential amino acids like lysine and tryptophan were important in improving nitrogen retention (Pellett and Ghosh, 2004). The processing of rice grain in terms of milling removes the bran layer from the endosperm. This implies not only the loss of a nutritionally valuable rice component in human diet but also a reduction of the quantity of rice available for human nutrition by around 10 to 15 per cent. The loss of protein from brown rice during milling ranged from 11.0 to $26 \%$ at milled rice recoveries of $86-90 \%$ and it was found that high protein rice offered greater resistance to milling by standard methods. Glutelin (alkali or acid soluble proteins) account for $80 \%$ or more of the total seed protein and thus the principal protein of whole grain (brown and milled rice), while albumin and globulin were the major proteins in rice bran (Cagampang et al., 1966; Juliano, 1972; Villareal and Juliano, 1978). Refined milling of successive layers of brown rice has revealed that the second outermost $5 \%$ fraction had the highest level of protein (Hogan et al., 1964).

Milled rice is the staple food of tropical Asia and it contributes 40 to 80 per cent of the calories and 40 per cent of the protein requirement (Shobarani et al., 2006). Compared to other protein sources, rice protein is deficient in lysine, the sulphur containing amino acid and tryptophan (FAO, 1957), but the lysine content of rice protein (3.5 to 4.0 percent) is highest among cereal proteins. A positive correlation of tryptophan with lysine content $(r=0.076)$ and a strong negative correlation with total protein content $(\mathrm{r}=-0.923)$ was recorded by Banerjee et.al (2011).

Environment affects the protein content of cereals and in rice, the grain protein accumulation of a variety exhibited a range of about $6 \%$ on dry weight basis (IRRI, 1963). The average protein content of milled rice is relatively low (about $7 \%$ at $14 \%$ moisture) whereas brown or dehulled rice contains about $8 \%$ protein. Increasing the protein content of rice would mean an increased supply of protein in rice based diets. Rice represents one of the largest ex-situ germplasm collections in the world which includes many land races breeding lines, donors and their wild relatives.

The biodiversity among these collections offers a valuable resource for various essential nutrients viz., zinc, iron, proteins and vitamins. Screening and exploitation of these resources is the only source for genetic improvement of protein and other essential micronutrients in an improved cultivar which opens up a new wizard for the elimination of malnutrition (Khush and Virk, 2002). Enriching rice with protein either through conventional or marker assisted introgression holds a great promise for sustainable food based solutions (Graham et al., 2001). The primary objective of the present investigation was to assess the variability of rice protein content in an association mapping panel for their subsequent utilization in the genetic enhancement of rice. 


\section{Materials and Methods}

\section{Genetic materials}

The materials which were utilized in the present study consisted of 150 germplasm accessions collected from different sources such as Paddy Breeding Station (PBS), Department of rice germplasm stock, International Rice Research Institute (IRRI) germplasm maintained at Paddy Breeding Station, Harvest Plus lines from Directorate of Rice Research, CHIR and ARB lines from West Bengal and Karnataka. It includes 50 landraces (traditional varieties) from Tamil Nadu, 52 lines from IRRI germplasm, four Improved Chinsurah lines from West Bengal, two IRRI varieties, five landraces from different parts of our country other than Tamil Nadu, 22 RPHP lines from Harvest Plus project, four ARB lines from Karnataka, one variety from Kerala (Pattambi), one improved line from Andhra Pradesh, three IRRI cultures, one variety from West Bengal and five improved varieties from Tamil Nadu.

\section{Experimental design}

The study was undertaken at Department of Rice, Tamil Nadu Agricultural University, Coimbatore during Kharif, 2015. Crop was raised under irrigated condition in an area of 26 cents with the recommended fertilizer dosage of 150:60:60 kg/ha of NPK. Once it attained physiological maturity, plants were harvested; seeds cleaned and dried up to the moisture level of $13 \%$.

Three samples per accession were evaluated for total soluble protein content. The dried seeds were dehusked using hand palm dehusker, ground evenly and sieved up to the talcum powder size with pestle and mortar. The powdered samples of unpolished rice were used for protein analysis using modified Lowry's method (Hartree, 1972).

\section{Extraction of protein}

\section{Sample preparation}

Powdered samples were subjected to extraction of protein by $0.1 \mathrm{M}$ phosphate buffer with $\mathrm{pH}$ of 7.4. One gram of sample from each entry was macerated with $50 \mathrm{ml}$ of phosphate buffer using Pestle and Mortar and centrifuged at $4000 \mathrm{rpm}$ for 20 minutes. The supernatants were collected for protein estimation by discarding the pellet. The above steps were performed for each entry separately until a clear extract was obtained. The extract was stored in deep freezer until further analysis.

\section{Protocol}

Total protein was estimated by modified Lowry's method given by Hartree, 1972. Determination of protein concentration by ultraviolet absorption depends on the presence of aromatic amino acids in the proteins. Although different proteins will have different amino acid compositions and thus different molar absorptivities, this method can be very accurate when comparing different solutions of the same protein (UK assays, 2017).

Extracted samples of $0.2 \mathrm{ml}$ were taken into test tube and the volume was made up to $1 \mathrm{ml}$ with distilled water. To it, $4.5 \mathrm{ml}$ of alkaline $\mathrm{CuSO}_{4}$ reagent was added and incubated at room temperature for 10 minutes followed by $0.5 \mathrm{ml}$ of Folin's phenol reagent. The contents were mixed well and the absorbance was measured at $650 \mathrm{~nm}$ after 15 minutes in a spectrophotometer. From the standard graph, the amount of protein in the given unknown solution was calculated.

\section{Results and Discussion}

Protein energy malnutrition affects $25 \%$ of children where their dietary intake is mainly 
on rice and staple crops have low levels of essential amino acids (Gearing, 2015). Rice is the principal source of carbohydrate and protein for the people in South East Asia (Cagampang et al., 1966) though it has the lowest protein level of $7.3 \mathrm{~g} / 100 \mathrm{~g}$ in brown rice among the cereals (Souci, Fuchmann and Kraut, 1986). Based on the mean true digestibility of egg, milk, cheese, meat and fish protein of 95 percent, the relative digestibility of milled rice is 93 percent (WHO, 1985) Recommended Dietary Allowance for protein per day is 0.8 gram per kilogram of bodyweight (Harvard Men's Health Watch, 2015). Though other sources of food rich in protein like egg, meat, milk, fish and pulses are present, their affordability across the section of society differs. The low income groups of people still depend on rice based diet. Protein energy and micronutrient malnutrition are widespread among rural and poor population. Hence, to meet out the required threshold level of protein in their rice based diet, finding a good source of rice protein from the available gene pool of rice is essential.

\section{Total protein content}

Among 150 germplasm accessions taken for our study, the protein content ranged from $7.54 \mathrm{~g} / 100 \mathrm{~g}$ in RG 96 (RP BIO 226) to 14.70 $\mathrm{g} / 100 \mathrm{~g}$ in RG1 (Mapillaisamba) with the coefficient of variation of $0.4 \%$ (Table 1 ). Fifty six lines were found to record significantly higher protein content than the grand mean of $8.88 \mathrm{~g} / 100 \mathrm{~g}$. About $62.67 \%$ (94 accessions) had low protein content (< $9.00 \mathrm{~g} / 100 \mathrm{~g}$ ) and $5.33 \%$ (eight accessions) recorded higher protein content of more than $10.50 \mathrm{~g} / 100 \mathrm{~g}$ of sample. About, $32.0 \%$ of accessions recorded moderate level of protein content with range of 9.01 to $10.50 \mathrm{~g} / 100 \mathrm{~g}$, (Fig. 1 and Table 2). It could be realized that in general most of the genotypes descend under the category of low protein. However, there is a handful of material representing $5.0 \%$ of the collections with high protein that gives the ray of hope that a significant variation exists among the rice germplasm materials taken for our investigation.

The earlier workers Kennedy and Burlingame (2003), Cao et al., (2009), Silveira et al., (2010) proposed a classification for the protein contents as high $(\geq 12 \%)$, medium $(11.9-9 \%)$, and low $(\leq 8.9 \%)$. Based on the range of protein content present in our association mapping panel, classification of high $(>10.5 \mathrm{~g} / 100 \mathrm{~g})$, moderate (9.01$10.5 \mathrm{~g} / 100 \mathrm{~g}$ ) and low levels of proteins $(<9.0 \mathrm{~g} / 100 \mathrm{~g})$ is followed. Heda and Reddy (1984) also considered values $>10 \%$ as high protein content analyzed in their $F_{1}$ to $F_{3}$ progenies of six crosses. Studies have shown that protein content in 1622 milled rice samples from 24 countries ranged from 4 to 14 percent and mean protein ranged from 6.3 to 9.2 percent and the overall mean was 7.8 percent (Juliano and Villareal, 1993) at $12 \%$ moisture.

Kennedy and Burlingame (2003) analyzed the protein contents of 2,869 genotypes of rice (2,674 O. sativa and 195 O. glaberrima), and found $8.8 \%$ as the mean for $O$. sativa, ranging from 4.5 to $15.9 \%$. The mean protein content of $8.88 \%$ in our present analysis comprising of $O$. sativa germplasm and the highest protein estimation of $14.70 \mathrm{~g} / 100 \mathrm{~g}$ is in almost close correspondence with their results.

The crude protein content of ten Philippine rice cultivars evaluated by Riza et al., (2004) showed a range of $6.3 \%$ (PR-27423-MS6) to 9.1\% (PR-31595-PSC101). Wide variation of as low as $2.8 \%$ to $9.9 \%$ for protein concentration in milled rice germplasm lines of Chhattisgarh have been reported by Chandel et al., (2005). Cao et al., (2009) found a wide variation in the levels of storage 
protein content $(7.38-15.41 \%)$ in Chinese varieties of $O$. sativa rice.

A wide variability of 6.19 to $10.75 \%$ with a mean value of $8.07 \%$ for protein content was observed by Banerjee et al., (2010) in brown rice of 46 genotypes including cultivated indica and japonica cultivars, germplasm accessions, advanced breeding lines and wild rice genotypes estimated by modified micro Kjeldahl method. Silveira et al., (2010) found a range of $4.4-20.2 \%$ for storage protein contents of 550 accessions, in the rice Core Collection of Embrapa, with an average of $10.31 \%$.

Protein content of milled grain among 258 land races of rice belonging to the extra-early group (95 days) maintained at IGKV, Raipur, Chhattisgarh ranged from $4.91 \%-12.08 \%$ with the mean of $6.63 \%$. Out of total 258 lines analyzed, fifty two were found with < $6.0 \%$ protein, 202 landraces were found to possess protein levels between $6.0-9.0 \%$ whereas, four lines were found with $>9.0 \%$ of grain protein (Banerjee et al.,, 2011). According to Totok et al., (2011), genotype $\mathrm{x}$ location interaction influenced grain protein content of 10 upland rice genotypes. They could identify three genotypes namely UNRAM 4E, UNRAM 9E, UNRAM 17E to possess stable protein content of $>8.0 \%$ protein in their milled rice by Kjeldahl's method. Mohanty et al., (2011) reported 16.41 and $15.27 \%$ of crude protein in brown rice of ARC 10063 and ARC 10075 rice accessions respectively on dry weight basis.

They observed the total free amino acid content to be higher in these accessions and lysine content was positively correlated with the grain protein content in contrary to the view of Juliano et al., (1964) and Cagampang et al., (1966). Hanumantrao (2013) estimated protein content in brown rice of 58 rice germplasm lines and varieties by modified
Micro kjeldahl method. The protein content varied from 6.09 to $11.2 \%$ estimated in the varieties CGR-436 and Danteshwari. By exploiting ARC 10075 as a donor, CR Dhan 310 (IET 24780) rice variety was developed with high protein content of $11 \%$ and rich in threonine and lysine (NRRI Annual Report 2014-2015).

Santos et al., (2013) analyzed twenty nine accessions of the wild rice species Oryza glumaepatula, collected from five Brazilian states and two commercial cultivars for storage protein profile and amino acid content. Total protein levels ranged from $14.94 \%$ (wild genotype BGA14280) to $9.07 \%$ (BGA14179). The control cultivars BRS Bonança and Primavera, together with the wild accessions BGA14210, BGA14232, BGA14233, and BGA14179, showed the lowest levels of total protein. Seven accessions possessed high protein with the range of 13.98 to $14.94 \%$. The second group had nine accessions with a range of 12.3 to $13.35 \%$. Thus, out of 29 genotypes evaluated, 16 had high total protein content and $13 \mathrm{had}$ medium protein content. A scrutiny of above findings on the estimation of protein content by different workers reveals that the low protein category ranged from 2.8 to $7.38 \%$ and the other extreme ranged from 9.07 to $15.9 \%$ in genotypes belonging to $O$. sativa. The lowest value of $7.54 \mathrm{~g} / 100 \mathrm{~g}$ recorded in this study material is above the range mentioned by earlier workers.

\section{Diversity of germplasm for total soluble protein content}

Cluster analysis was performed to construct a dendrogram depicting the diverse sources of the genotypes in terms of geographic location, (Fig. 2) in order to compare with the three groupings given in Table 2 and also with the protein content classification adopted by earlier workers. 
Table.1 Total available protein content $(\mathrm{g} / 100 \mathrm{~g})$ in 150 rice germplasm accessions

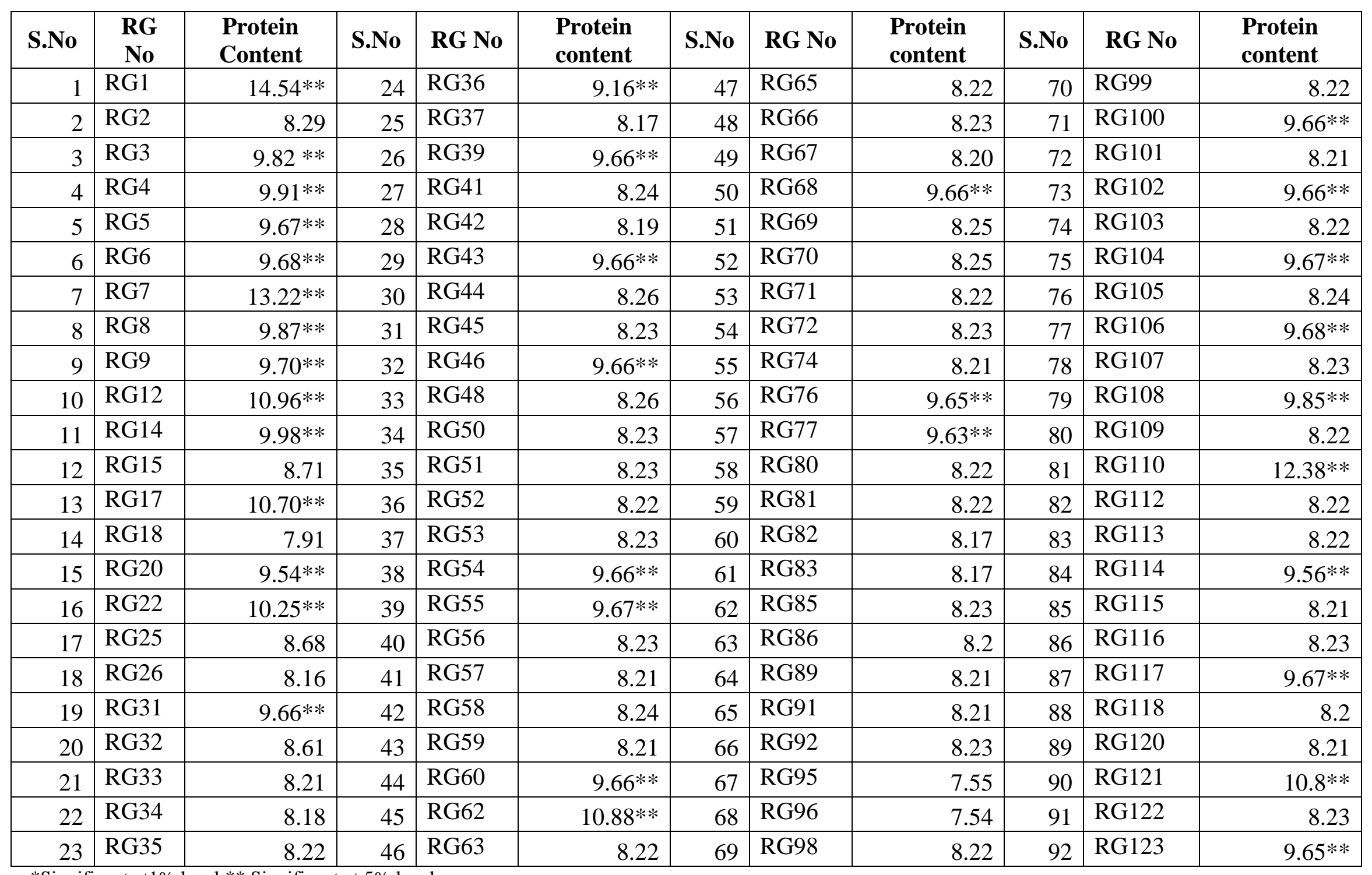

*Significant at $1 \%$ level $* *$ Significant at $5 \%$ level 
Table.1 Contd...

\begin{tabular}{|c|c|c|c|c|c|c|c|c|c|c|c|}
\hline S.No & $\begin{array}{c}\text { Accession } \\
\text { No }\end{array}$ & $\begin{array}{l}\text { Protein } \\
\text { content }\end{array}$ & S.No & $\begin{array}{c}\text { Accession } \\
\text { No }\end{array}$ & \begin{tabular}{|l|} 
Protein \\
content
\end{tabular} & S.No & $\begin{array}{c}\text { Accession } \\
\text { No }\end{array}$ & $\begin{array}{l}\text { Protein } \\
\text { content }\end{array}$ & S.No & $\begin{array}{c}\text { Accession } \\
\text { No }\end{array}$ & $\begin{array}{l}\text { Protein } \\
\text { content }\end{array}$ \\
\hline 93 & RG124 & 8.22 & 107 & RG142 & 8.21 & 121 & RG159 & $9.78 * *$ & 135 & RG175 & $9.77 * *$ \\
\hline 94 & RG126 & $9.66 * *$ & 108 & RG143 & $9.77 * *$ & 122 & RG160 & 8.17 & 136 & RG176 & $9.77 * *$ \\
\hline 95 & RG127 & $9.66 * *$ & 109 & RG145 & $9.65 * *$ & 123 & RG161 & 8.13 & 137 & RG178 & $9.77 * *$ \\
\hline 96 & RG128 & $9.66 * *$ & 110 & RG146 & 8.22 & 124 & RG162 & $9.75 * *$ & 138 & RG180 & 8.40 \\
\hline 97 & RG129 & 8.41 & 111 & RG147 & 8.22 & 125 & RG163 & 8.22 & 139 & RG181 & 8.22 \\
\hline 98 & RG130 & 8.24 & 112 & RG148 & $9.66 * *$ & 126 & RG164 & 8.22 & 140 & RG182 & $9.80 * *$ \\
\hline 99 & RG131 & 8.21 & 113 & RG149 & 8.22 & 127 & RG165 & 8.58 & 141 & RG183 & 8.38 \\
\hline 100 & RG132 & 8.21 & 114 & RG150 & 8.24 & 128 & RG166 & 8.23 & 142 & RG184 & $9.61 * *$ \\
\hline 101 & RG133 & $9.16 * *$ & 115 & RG151 & 8.41 & 129 & RG168 & $9.80 * *$ & 143 & RG185 & $9.64 * *$ \\
\hline 102 & RG134 & 8.22 & 116 & RG152 & 8.18 & 130 & RG169 & 8.13 & 144 & RG186 & 8.38 \\
\hline 103 & RG135 & 8.42 & 117 & RG154 & 8.38 & 131 & RG170 & 8.29 & 145 & RG187 & $9.55^{* *}$ \\
\hline 104 & RG136 & $9.56 * *$ & 118 & RG156 & 8.17 & 132 & RG172 & 8.12 & 146 & RG188 & $9.67 * *$ \\
\hline 105 & RG137 & 8.34 & 119 & RG157 & 8.18 & 133 & RG173 & 8.22 & 147 & RG189 & 8.43 \\
\hline 106 & RG141 & 8.22 & 120 & RG158 & 8.19 & 134 & RG174 & 8.19 & 148 & RG190 & $9.82 * *$ \\
\hline \multicolumn{11}{|c|}{ Grand mean } & 8.88 \\
\hline \multicolumn{11}{|c|}{ Range } & $\begin{array}{l}7.54- \\
14.54 \\
\end{array}$ \\
\hline \multicolumn{11}{|c|}{ SE (d) } & 0.032 \\
\hline \multicolumn{11}{|c|}{$\mathrm{CD}(0.05 \%)$} & 0.062 \\
\hline \multicolumn{11}{|c|}{$\mathrm{CD}(0.01 \%)$} & 0.081 \\
\hline \multicolumn{11}{|c|}{$\mathrm{CV} \%$} & 0.44 \\
\hline
\end{tabular}


Table. 2 Grouping of germplasm lines based on mean protein content

\begin{tabular}{|c|c|c|c|c|}
\hline $\begin{array}{c}\text { Protein content } \\
\text { g/100g }\end{array}$ & Individuals & $\begin{array}{l}\text { Number of } \\
\text { Accessions }\end{array}$ & $\begin{array}{l}\text { Percentage of } \\
\text { individuals }\end{array}$ & *Grouping \\
\hline$>10.51$ & RG1,RG7,RG12,RG17,RG62,RG110,RG121,RG191 & 8 & 5.33 & High \\
\hline$<9.00$ & $\begin{array}{l}\text { RG2,RG15,RG18,RG25,RG26,RG32,RG33,RG34,RG35,RG37, } \\
\text { RG41,RG42,RG44,RG45,RG48,RG50,RG51,RG52,RG53,RG56, } \\
\text { RG57,RG58,RG59,RG63,RG65,RG66,RG67,RG69,RG70,RG71, } \\
\text { RG72,RG74,RG80,RG81,RG82,RG83,RG85,RG86,RG89,RG91, } \\
\text { RG92,RG95,RG96,RG98,RG99,RG101,RG103,RG105,RG107, } \\
\text { RG109,RG112,RG113,RG115,RG116,RG118,RG120,RG122, } \\
\text { RG124,RG129,RG130,RG131,RG132,RG134,RG135,RG137, } \\
\text { RG141,RG142,RG146,RG147,RG149,RG150,RG151,RG152, } \\
\text { RG154,RG156,RG157,RG158,RG160,RG161,RG163,RG164, } \\
\text { RG165,RG166,RG169,RG170,RG172,RG173,RG174,RG180, } \\
\text { RG181,RG183,RG186,RG189,RG192 }\end{array}$ & 94 & 62.67 & Low \\
\hline
\end{tabular}


Table.3 Clustering and grouping pattern of rice germplasm using UPGMA method

\begin{tabular}{|c|c|c|c|c|c|}
\hline $\begin{array}{c}\text { Main } \\
\text { cluster }\end{array}$ & $\begin{array}{c}\text { Sub } \\
\text { cluster }\end{array}$ & Accessions & $\begin{array}{c}\text { No. of } \\
\text { Accessions }\end{array}$ & $\begin{array}{l}\text { Cluster mean } \\
\text { range(g/100g) }\end{array}$ & *Grouping \\
\hline \multirow[t]{2}{*}{ I } & 1 & RG1 & 1 & 14.54 & High \\
\hline & 2 & RG7,RG110 & 2 & 13.22 to 12.38 & High \\
\hline \multirow[t]{2}{*}{ II } & 1 & RG12,RG62,RG17,RG191,RG121 & 5 & 10.70 to 10.96 & High \\
\hline & 2 & $\begin{array}{l}\text { RG3,RG4,RG5,RG6,RG8,RG9,RG14,RG20, } \\
\text { RG22,RG31,RG36,RG39,RG43,RG46,RG54, } \\
\text { RG55,RG60,RG68,RG76,RG77,RG100,RG102, } \\
\text { RG104,RG106,RG108,RG114,RG117,RG123, } \\
\text { RG126,RG127,RG128,RG133,RG136,RG143, } \\
\text { RG145,RG148,RG159,RG162,RG168,RG175, } \\
\text { RG176,RG178,RG182,RG184,RG185,RG187, } \\
\text { RG188,RG190 }\end{array}$ & 48 & 9.16 to 10.25 & Moderate \\
\hline
\end{tabular}


Annexure.1 Details of rice genotypes falling under high and moderate levels of total soluble protein content

\begin{tabular}{|c|c|c|c|c|c|c|c|}
\hline S.No & \begin{tabular}{|c|} 
Main \\
Cluster
\end{tabular} & $\begin{array}{c}\text { Sub } \\
\text { cluster }\end{array}$ & Group & RG.No. & Genotype & Parentage & Origin \\
\hline 1 & $\mathrm{I}$ & 1 & High & RG1 & Mapillaisamba & Landrace & Tamil Nadu, India \\
\hline 2 & $\mathrm{I}$ & 2 & High & RG7 & Kudai vazhai & Landrace & Tamil Nadu, India \\
\hline 3 & $\mathrm{I}$ & 2 & High & RG110 & Norungan & Landrace & Tamil Nadu, India \\
\hline 4 & II & 1 & High & RG12 & Vellai chithiraikar & Landrace & Tamil Nadu, India \\
\hline 5 & II & 1 & High & RG 62 & Purpleputtu & Landrace & Tamil Nadu, India \\
\hline 6 & II & 1 & High & RG17 & Sivapuchithiraikar & Landrace & Tamil Nadu, India \\
\hline 7 & II & 1 & High & RG191 & IG 15(EC 728910- 117901) & Sze guen zim & China \\
\hline 8 & II & 1 & High & RG121 & IG 74(EC 728622- 117517) & Kinandang Patong::IRGC23364-1 & IRRI, Philippines \\
\hline 9 & II & 2 & Moderate & RG3 & Senkar & Landrace & Tamil Nadu, India \\
\hline 10 & II & 2 & Moderate & RG4 & Murugankar & Landrace & Tamil Nadu, India \\
\hline 11 & II & 2 & Moderate & RG5 & CHIR 6 & Improved chinsurah & West Bengal \\
\hline 12 & II & 2 & Moderate & RG6 & CHIR 5 & Improved chinsurah & West Bengal \\
\hline 13 & II & 2 & Moderate & RG8 & CHIR 8 & Improved chinsurah & West Bengal \\
\hline 14 & II & 2 & Moderate & RG9 & Kuruvai kalanjiyam & Landrace & Tamil Nadu, India \\
\hline 15 & II & 2 & Moderate & RG14 & Jothi & Variety & Kerala,India \\
\hline 16 & II & 2 & Moderate & RG20 & Kalvalai & Landrace & Tamil Nadu, India \\
\hline 17 & II & 2 & Moderate & RG22 & IR 36 & $\begin{array}{l}\text { IR1561-228-L2/IR1737/ /CR94- } \\
13\end{array}$ & IRRI, Philippines \\
\hline 18 & II & 2 & Moderate & RG31 & Chinthamani & Landrace & Tamil Nadu, India \\
\hline 19 & II & 2 & Moderate & RG36 & Kattikar & Landrace & Tamil Nadu, India \\
\hline 20 & II & 2 & Moderate & RG39 & Kaatu ponni & Landrace & Tamil Nadu, India \\
\hline 21 & II & 2 & Moderate & RG43 & RPHP 129 & Kamad & Jammu and Kashmir \\
\hline 22 & II & 2 & Moderate & RG46 & IG 4 (EC 729639- 121695) & TD2: : IRGC 9148-1 & IRRI, Philippines \\
\hline 23 & II & 2 & Moderate & RG54 & PTB 19 & Variety & Kerala, India \\
\hline 24 & II & 2 & Moderate & RG55 & IG 67(EC 729050- 120988) & $\begin{array}{l}\text { IR77384-12-35-3-12-1- } \\
\text { B::IRGC117299-1 }\end{array}$ & IRRI, Philippines \\
\hline 25 & II & 2 & Moderate & RG60 & Rama kuruvaikar & Landrace & Tamil Nadu, India \\
\hline 26 & II & 2 & Moderate & RG68 & IG 63(EC 728711- 117674) & Caawa/Fortuna & IRRI, Philippines \\
\hline 27 & II & 2 & Moderate & RG76 & Matta kuruvai & Landrace & Tamil Nadu, India \\
\hline
\end{tabular}




\begin{tabular}{|c|c|c|c|c|c|c|c|}
\hline 28 & II & 2 & Moderate & RG77 & Karuthakar & Landrace & Tamil Nadu, India \\
\hline 29 & II & 2 & Moderate & RG100 & IG 7(EC 729598- 121648) & Vary manity:: IRGC69910-1 & IRRI, Philippines \\
\hline 30 & II & 2 & Moderate & RG102 & Varakkal & Landrace & Tamil Nadu, India \\
\hline 31 & II & 2 & Moderate & RG104 & IG 53(EC 728752- 117719) & Carolina rinolda barsani & Uruguay \\
\hline 32 & II & 2 & Moderate & RG106 & Katta samba & Landrace & Tamil Nadu, India \\
\hline 33 & II & 2 & Moderate & RG108 & Red sirumani & Landrace & Tamil Nadu, India \\
\hline 34 & II & 2 & Moderate & RG114 & RPHP 159 & Radhuni pagal & Bangladesh \\
\hline 35 & II & 2 & Moderate & RG117 & IG 65(EC 729024- 120958) & GODAHEENATI:: IRGC31393-1 & IRRI, Philippines \\
\hline 36 & II & 2 & Moderate & RG123 & IG 2(EC 729808-121874) & BLUEBONNET 50::IRGC1181 & IRRI, Philippines \\
\hline 37 & II & 2 & Moderate & RG126 & Kallimadayan & Landrace & Tamil Nadu, India \\
\hline 38 & II & 2 & Moderate & RG127 & IG 10(EC 729686- 121743) & Hasan seralirGC79564-C1 & IRRI, Philippines \\
\hline 39 & II & 2 & Moderate & RG128 & IG 75(EC 728587- 117420) & Aedal:: IRGC55441-1 & IRRI, Philippines \\
\hline 40 & II & 2 & Moderate & RG133 & IG 42(EC 728798- 117774) & Kalubala vee & Srilanka \\
\hline 41 & II & 2 & Moderate & RG136 & IG 8(EC 729601- 121651) & Xi you zhan :: IRGC78574-1 & IRRI,Philippines \\
\hline 42 & II & 2 & Moderate & RG143 & IG 46(IC 471826- 117647) & Baber & India \\
\hline 43 & II & 2 & Moderate & RG145 & IG 60(EC 728730- 117695) & Creole & Belize \\
\hline 44 & II & 2 & Moderate & RG148 & Chinna aduku nel & Landrace & Tamil Nadu, India \\
\hline 45 & II & 2 & Moderate & RG159 & Sembala & Landrace & Tamil Nadu, India \\
\hline 46 & II & 2 & Moderate & RG162 & IR 64 & $\begin{array}{l}\text { IR 5857-33-2-1 x IR 2061-465-1- } \\
5-5\end{array}$ & IRRI, Philippines \\
\hline 47 & II & 2 & Moderate & RG168 & Haladichudi & Landrace & Odisha, India \\
\hline 48 & II & 2 & Moderate & RG175 & Vellai kudaivazhai & Landrace & Tamil Nadu, India \\
\hline 49 & II & 2 & Moderate & RG176 & Kodai & Landrace & Tamil Nadu, India \\
\hline 50 & II & 2 & Moderate & RG178 & IG 17(EC 728900- 117889) & Sigadis & Indonesia \\
\hline 51 & II & 2 & Moderate & RG182 & ARB 59 & Variety & Karnataka, India \\
\hline 52 & II & 2 & Moderate & RG184 & IG 18(EC 728892- 117880) & Seratoes hari & Indonesia \\
\hline 53 & II & 2 & Moderate & RG185 & RPHP 36 & Variety, TKM 9 & Tamil Nadu, India \\
\hline 54 & II & 2 & Moderate & RG187 & Vadakathi samba & Landrace & Tamil Nadu, India \\
\hline 55 & II & 2 & Moderate & RG188 & RPHP 80 & $24(\mathrm{~K})$ & $\begin{array}{l}\text { Andhra Pradesh, } \\
\text { India }\end{array}$ \\
\hline 56 & II & 2 & Moderate & RG190 & IG 26(IC0590943- 121899) & Basmati 370 ::IRGC 3750-1 & IRRI, Philippines \\
\hline
\end{tabular}


Fig.1 Pie chart representation of protein content among 150 rice germplasm accessions

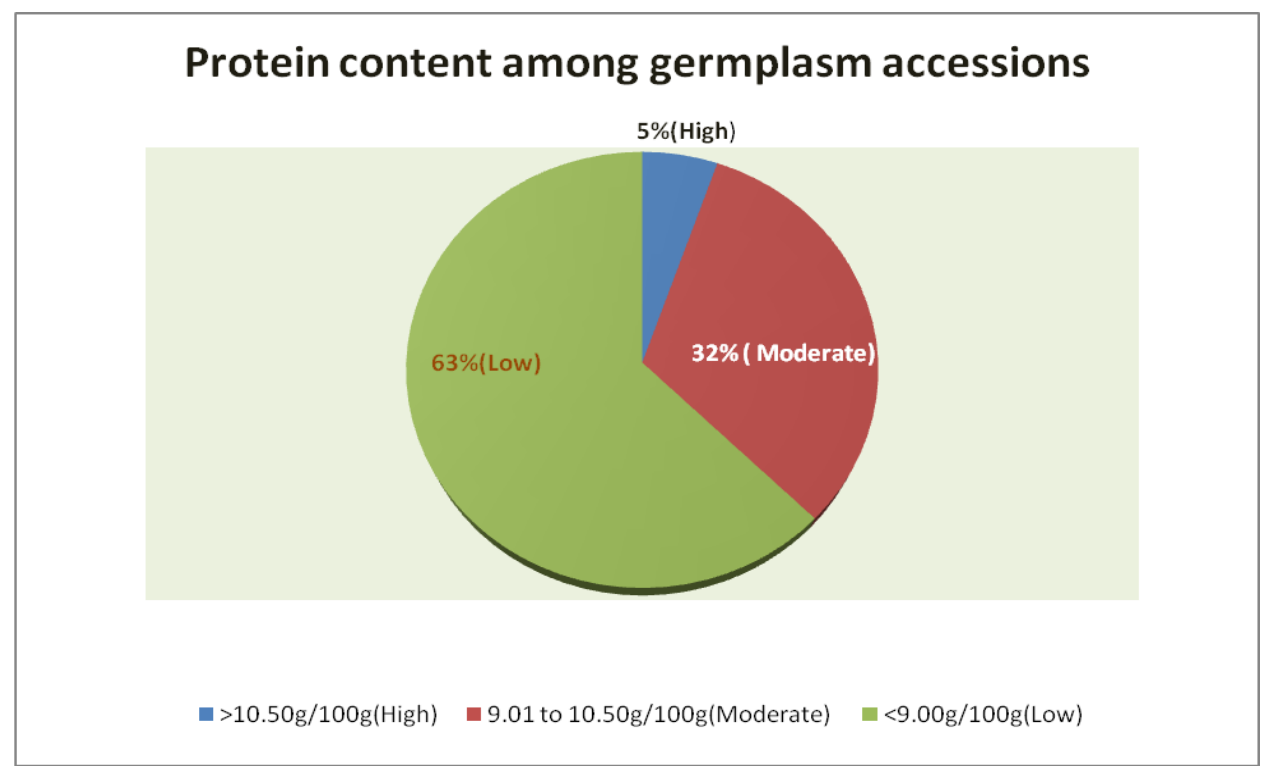

Fig.2 Clustering and grouping pattern of rice germplasm based on protein content

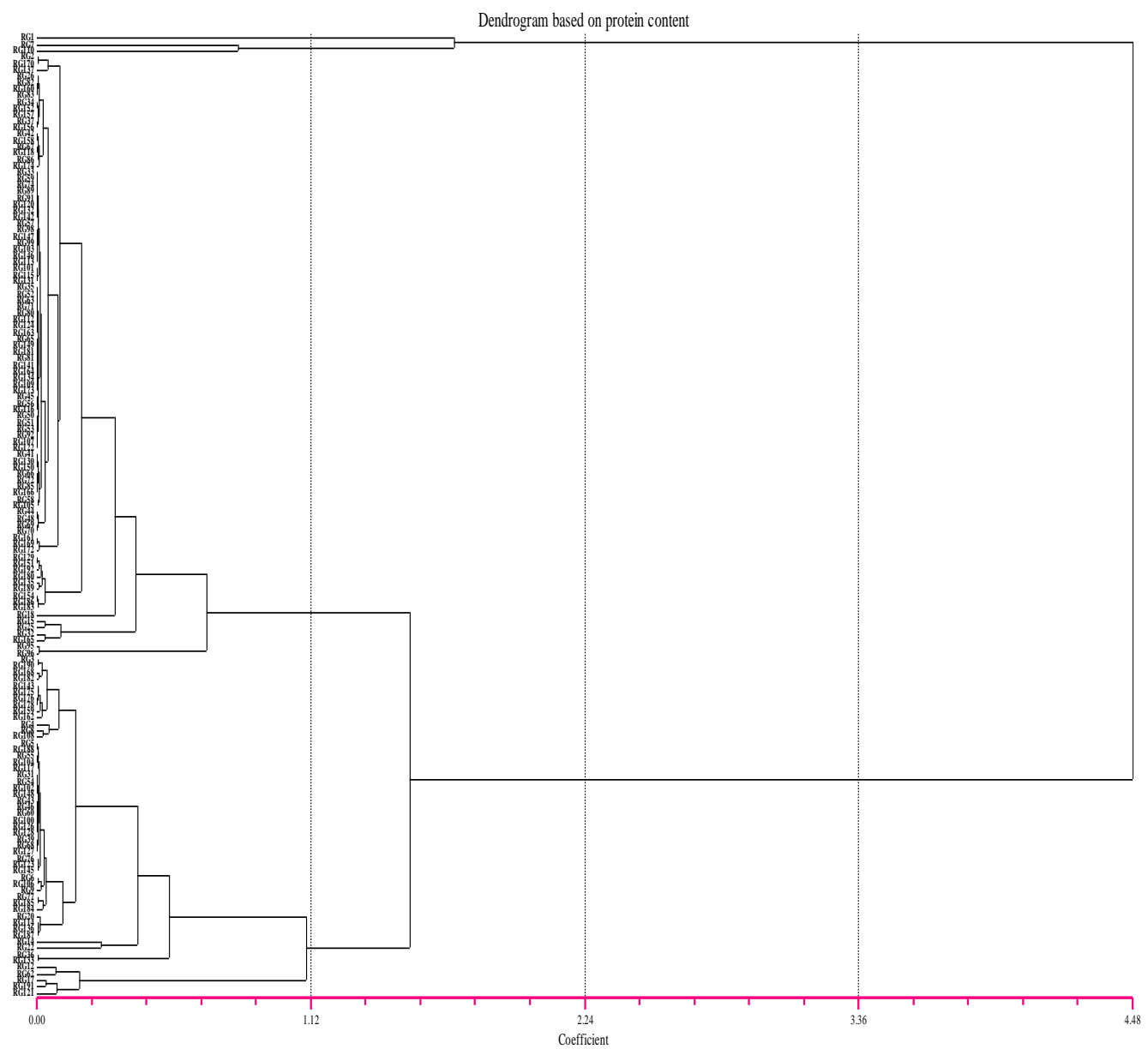


There was a formation of two major clusters at similarity coefficient of 2.24 (Table 3). Main Cluster I comprised of three genotypes namely RG1 (Mapillaisamba), RG7 (Kudaivazhai) and RG110 (Norungan) with very high protein content in the range of 12.38 to $14.54 \mathrm{~g} / 100 \mathrm{~g}$ rice sample. Thus it fitted perfectly with the classification of high protein content $(>12 \%)$ by earlier workers.

Major cluster II accommodated 147 genotypes branching into three sub clusters. Sub-cluster I with five accessions namely RG12 (Vellaichithiraikar), RG62 (Purpleputtu), RG17 (Sivapuchithiraikar), RG191 (IG15) and RG121 (IG74) were categorized as possessing high protein content in the range of 10.70 to $10.96 \mathrm{~g} / 100 \mathrm{~g}$. Subcluster 2 had 48 accessions (32.0\%) with moderate protein content in the range of 12.01 to $19.01 \mathrm{~g} / 100 \mathrm{~g}$. Sub-cluster 3 had 94 genotypes representing $62.7 \%$ of the material with low protein content which ranged from 7.54 to $8.71 \mathrm{~g} / 100 \mathrm{~g}$.

Cluster analysis grouped the 258 rice landraces into ten clusters (Banerjee et al., 2011). The cluster IV consisted of maximum number of 36 rice landraces followed by cluster III containing 31 landraces, cluster VIII containing 30 landraces. Cluster VIII consisted of minimum number of 19 landraces.

A UPGMA dendrogram was derived through Nei's unbiased genetic similarity coefficients among 173 rice landraces based on their protein profile by Pervaiz et al.,(2011). Four distinct major clusters were derived at similarity value of 0.91 . The first cluster consisted of four accessions with no or very low glutelin. The second cluster consisted of a single accession 6708 that has no $W x$ gene product and showing very low amylose contents, while alpha-2 and 3 of glutelin subunits. Third cluster consisted of nine accessions along with Kinmaze (Japonica standard) with no $W x$ gene product, only alpha-1 subunit of glutelin polypeptide and 32 $\mathrm{kDa}$ peptide were absent, while 'c' subunit of $13 \mathrm{kDa}$ prolamin was also missing. Fourth cluster consisted of majority of accessions numbering 160 accounting for $91 \%$ of total accessions including IR36 (Indica standard). No significant association of geographical location and variation in seed protein profile was observed. The landraces from different geographical zones were grouped together in same clusters.

The present study of the total available protein content in 150 accessions of whole grains using modified Lowry's method exhibited two-fold increase in protein content. Modified Lowry's method was considered as highly feasible method to estimate even the negligible amount of protein and this method provides the real picture of soluble protein level which directly depicts the bio-available level of protein content in the human body. In this study approximately $95 \%$ of the genotypes exhibited low to moderate level of protein.

It was well established from our experiment that high protein lines RG1 (Mapillaisamba), RG7 (Kudaivazhai) and RG110 (Norungan) grouped in cluster I belonged to local landraces of Tamil Nadu. Also out of five genotypes falling in subcluster 1 of main cluster II, except two exotic lines from IRRI (RG 121) and China (RG 191), three others viz., RG 12 (Vellaichithiraikar), RG62 (Purple puttu) and RG17 (Sivappuchithiraikar) are landraces of Tamil Nadu. Landraces of rice are still the storehouse of wealth of genetic diversity for different traits in rice. These landraces are still on cultivation in certain pockets by farmers and marketed as specialty rices which are not affordable by low income groups. They are poor yielding and possess traits like tallness, lodging, photosensitivity, 
fertilizer non-responsive etc. which restrict their use as a commercial cultivar. Hence they can be recommended as promising parent material/ donor for breeding rice with enhanced protein level through hybridization and conventional selection as practiced by Heda and Reddy (1984) in six crosses from $F_{1}$ to $F_{3}$. The mean protein content of $F_{1}$ was higher than the protein content of respective high protein parent in five of the crosses. In $\mathrm{F}_{2}$, the protein content was low in many of the segregants and the frequency of desirable segregants increased in $F_{3}$. The advent of modern tools aid in the identification of genes /QTLs for specific traits and hasten the conventional breeding through marker assisted selection or transgenic approaches in biofortification programmes.

The study has identified the desirable lines with high protein content namely RG1 (Mapillai Samba - 14.54 g/100g), RG7 (Kudaivazhai - 13.22 g/100g), RG12 (Vellaichithiraikar - $10.96 \mathrm{~g} / 100 \mathrm{~g}$ ), RG17 (Sivapuchithiraikar - $10.70 \mathrm{~g} / 100 \mathrm{~g}$ ), RG62 (Purple puttu- 10.88 g/100g), RG110 (Norungan - 12.38 g/100g), RG121 (IG74 $10.80 \mathrm{~g} / 100 \mathrm{~g}$ ) and RG191 (IG15 - 10.74 $\mathrm{g} / 100 \mathrm{~g})$. Accessions from high and low protein content can be utilized in recombination breeding to map the genomic regions associated with protein content and also identify markers specific to the trait. Also, they can be used as donors in a recombination breeding programme with either high or moderate protein lines with acceptable phenotype to isolate the enhanced level of protein in recombinants with high yielding better plant types in the long run to achieve sustainability in rice production along with nutritional security.

The nutritional enhancement of rice grain especially protein is a primary objective of researchers to provide nutritional security for saving human community especially children.
To meet these challenges, the role of plant breeders and biotechnologists together to explore efficient breeding strategies that integrate genomic technologies by using available germplasm resources to a new revolution in the field of plant breeding for complex traits has been emphasized by Perezde-Castro et al., (2012). The nutritional traits of importance in rice grains and their enhancement using associated genes and QTLs through advanced approaches has been recently reviewed by Mahender et al., (2016).

The present knowledge on the total accumulation of protein in rice accessions would be helpful for breeders to enhance the level of nutrient accumulation in rice grains.

In near future, conventional breeding along with marker assisted selection or advanced genomic strategies will give fruitful results to achieve the targeted level of accumulation of proteins and other important nutrients in grains.

\section{Acknowledgement}

The authors are grateful to Indian Council of Agricultural Research (ICAR), New Delhi for providing financial assistance through the 'Consortium Research Platform on Rice Biofortification'.

\section{References}

Anumalla Mahender, Annamalai Anandan, Sharat Kumar Pradhan and Elssa Pandit. 2016. Rice grain nutritional traits and their enhancement using relevant genes and QTLs through advanced approaches. Springer Plus. 5:2086

Banerjee, S., D. Sharma, S. Verulkar and G. Chandel. 2010. Use of in silico and semi quantitative RT-PCR approaches to develop nutrient rich rice (Oryza sativa L.). Ind J Biotechnol.9(2):203-212

Banerjee, S., Chandel, G., Mandal, N., Meena, B. M., and T. Saluja. 2011. Assessment of 
nutritive value in milled rice grain of some Indian rice landraces and their molecular characterization. Bangladesh J. Agril. Res, 36 (3), pp. 369-380.

Cagampang, G.B., Cruz, L.J., Espiritu, S.G., Santiago, R.G., Juliano, B.O., 1966. Studies on the extraction and composition of rice proteins. Cereal Chem. 43:145 155.

Cao, D., M. Hou, Y.S. Guan, M. Jiang, Y. Yang and H.F.Gou. 2009. Expression of HIF1alpha and VEGF in colorectal cancer: association with clinical outcomes and prognostic implications. BMC Cancer. 9: 432

Chandel, G., M. S. Dudhare, T. Saluja, S. M. Shiva, Y. Sharma, A. K. Geda, G. R. Sahu, V. N. Mishra and S. K. Katiyar. 2005. Screening rice accessions for nutritional quality traits to achieve nutritionally balanced rice. In 5th International Rice Genetics Symposium, Nov. 19-23, 60-61.

da Silveira, C.H., D.E.V. Pires, R.C. Minardi, C. Ribeiro, C.J.M. Veloso, J.C.D. Lopes, W. Meira and G. Neshich G. 2010. Protein cutoff scanning: a comparative analysis of cutoff dependent and cutoff free methods for prospecting contacts in proteins. Proteins: Struct. Funct. Bioinf. 74: 727743

Food and Agriculture Organization.1957. Protein requirements: report of the FAO committee. Rome: FAO Nutritional Studies No 16, pp70-107

Gearing, M.E. 2015. Good as gold: Can golden rice and other biofortifed crops prevent malnutrition? Science in the News, Harvard University.

Graham, R.D., R.M. Welch, and H.E. Bouis. 2001. Addressing micronutrient malnutrition through enhancing the nutritional quality of staple foods: Principles, perspectives and knowledge gaps. Adv. Agron. 70:77-142.

Hartree,E.A. 1972. Determination of Protein: A Modification of the Lowry Method That Gives a Linear Photometric Response Analytical biochemistry. 48, 422-427

Harvard Men's Health Watch, 2015. https://www.health.harvard.edu/newsletter s/harvard_mens_health_watch/2015/june

Heda. G.D. and Reddy. G.M. 1984. Inheritance studies of morphological and quality characteristics in Rice. SABRAO journal. 16(2), 153- 156.

Hogan, J. T., F. L. Normand, H. J. Deobald. 1964. Method for removal of successive surface layers from brown and milled rice. Rice J. 67, 27.

IRRI. 1963. Annual Report for 1963, pp. 149-161. The Institute: Los Baflos, Laguna, Philippines.

Juliano, B. 0.. Cagampang, G. B., Cruz, L. J., and Santiago. R. G. 1964. Some physicochemical properties of rice in Southeast Asia. J. Ser. No. 20. 275-285.

Juliano, B.O and Villarreal, C.P.1993. Grain Quality Evaluation of World Rice. P.148.International Rice Research Institute, Philippines.

Juliano, B.O. 1972. The rice caryopsis and its composition. In D.F. Houston, ed. Rice chemistry and technology, p. 16-74. St Paul, MN, USA,

Kennedy, G and B. Burlingame. 2003. Analysis of food composition data on rice from a plant genetic resources perspective. Food Chem. 80,589-596.

Khush G.S and P.S. Virk. 2002. Rice improvement: past, present and future. In M.S. Kang ed., Crop improvement: Challenges in $21^{\text {st }}$ century. Food Products Press, New York. Pp. 17-42

Lowry, O.H., N.J. Rosebrough, A.L. Farr, and R.J. Randall. 1951. J. Biol. Chem 193: 265 (The original method).

Mahendra, S., C. Ravi, B. Viswanathan, A. Gulati and S. Ramchander. 2004. Economic liberalization, programs and household food security: A case study of India IFPRI. Markets, Trade and Industry (MTI) Discussion paper No.68.

Mohanty A, Marndi BC, Sharma S, Das A (2011) Biochemical characterization of two high protein rice cultivars from Assam rice collections. Oryza. 48(2):171-174

Narayanan Deepa, Robert chambers, Meera. K.Shah and Patti Petesch. 2000. Voices of the poor: can Anyone hear us? Oxford University press, New York.

NRRI Annual Report (2014-2015) ICAR- 
National Rice Research Institute (NRRI),Cuttack

Patil Arun Hanumantrao. 2013. DNA fingerprinting and association mapping for grain protein content in rice (Oryza sativa L).M.Sc.(Ag.) Thesis.

Per Pinstrup-Andersen, Rajul Pandya-Lorch, Mark.W. Rosegrant. 1999. World food prospects: Critical issues for the early twenty -first century. 2020 vision food policy report. IFPRI, Washington. D.C.

Pérez-de-Castro. A.M., S. Vilanova, J. Cañizares, L. Pascual, J.M. Blanca, M.J. Díez, J. Prohens and B. Picó. 2012. Application of Genomic Tools in Plant Breeding. Current Genomics, 13, 179-195

Peter, L., Pellett and Shibani Ghosh. 2004. Lysine fortification: Past, present, and future. Food and Nutrition Bulletin, vol. 25, no. 2.pp107-113

Riza, G., A. Ramos, R. V. Manaois, S. S. Escubio, G. D. Garcia, E. C. Arocena and L. S. Sebastian. 2004. Grain quality and iron density of Philippine rice cultivars. 4th International Crop Science Congress.pp.527-531.

Santos, M.A.; Nicolás, M.F.; Hungria, M. 2006. Identifcation of QTL associated with the symbiosis of Bradyrhizobium japonicum, B. elkanii and soybean = Identifcação de QTL associados à simbiose entre Bradyrhizobium japonicum, B.elkanii e soja. Pesquisa Agropecuária Brasileira 41:
67-75 (in Portuguese, with abstract in English).

Shobha Rani, N., M.K. Pandey, G.S.V. Prasad and I. Sudharshan. 2006. Historical significance, grain quality features and precision breeding for improvement of export quality basmati varieties in India. Indian J Crop Sci 1(1-2):29-41

Souci, S.W, W. Fachmann and H.Kraut. 1986. Food Composition and Nutrition Tables 1986/87, Wissenschaftliche Verlagsgesellschaft, Stuttgart.

Totok, A. D. H., Suwarto, A., Riyanto, D., Susanti, N., Farid, I. N., Kantun, Suwarno and Shao-Hui.2011. Variability of grain protein content in improved upland rice genotypes and its response to locations. Electronic J. Pl. Breed. 2(2): 200-208.

UK Essays, 2017.https://www.ukessays.com/ essays/biology/lowry-method-the-totallevel-of-protein-biology-essay.php

Villareal, R. M. and B.O. Juliano. 1978. Properties of glutelin from mature and developing rice grain. Phytochemistry 17:177.

WHO 1985. http://www.fastonline.org/CD3 WD_40/INPHO/VLIBRARY/T0567E/EN /T0567E0D.HTM

Zahida Hassan Pervaiz, Sadia Tehrim, M. Ashiq Rabbani, M.S. Masood and Salman A. Malik. 2011. Diversity in major seed storage proteins of rice landraces of Pakistan. Pak. J. Bot., 43(3): 1607-1612.

\section{How to cite this article:}

Aiyswaraya, S., R. Saraswathi, S. Ramchander, R. Vinoth, D. Uma, D. Sudhakar and Robin, S. 2017. An Insight into Total Soluble Proteins across Rice (Oryza sativa L.) Germplasm Accessions. Int.J.Curr.Microbiol.App.Sci. 6(12): 2254-2269.

doi: https://doi.org/10.20546/ijcmas.2017.612.261 